\title{
THE CORRELATION BETWEEN THE QUALITY OF WORK LIFE AGAINST THE PERFORMANCE OF THE EMPLOYEES OF OGAN ILIR DISTRICT GENERAL HOSIPTAL, SOUTH SUMATERA IN 2018
}

\author{
* Herliyanti Yadi, ** Dumilah Ayuningtyas \\ * Faculty of Public Health, Universitas Indonesia \\ ** Faculty of Public Health, Universitas Indonesia
}

Email : herliyantiyadi@yahoo.com

\begin{abstract}
A favorable work environment will influence the quality of work life, would create quality human resources, and support the improvements in the quality of services. To discover the correlation betweem the quality of work life and the employees' performance at Ogan Ilir District General Hospital, a study was performed in March-April 2018. The study was a cross sectional quantitative study on 315 civil servants and voluntary staff at the hospital. Univariate, bivariate, and multivariate analysis was performed using the chi-square and the double regression prediction/determinant model. We discovered that the quality of the work life at the hospital was lacking, particularly for pride in their place of work, employee involvement/participation, and the facilities provided to the employees. It was also discovered that of the 315 employees, 164 (51.1\%) employees had low performance index and there was a significant correlation between the employee involvement/participation and the facilities provided to the employees with their performance. Therefore, the three components that was correlated strongly with employee performance was employee involvement/participation [Odds Ratio (OR): 2.190, Confidence Interval (CI): 95\%, P <0.001], facilities provided (OR: 2.670; CI 95\%, $\mathrm{p}<0.000$ ), and work safety (OR: 0.972 , CI 95\%, $\mathrm{p}=0.911)$.
\end{abstract}

Keywords: Quality of Work Life, Employee Performance, Hospital, Ogan Ilir.

\section{INTRODUCTION}

One of the sectors that plays a big role in the national development is the health sector. A healthy community is expected to create good quality human resources. The quality of human resources should also supported with a comfortable work environment that would induce creativity, loyality, and good work ethics. According to Muljani et al. and Analisa, there is a direct correlation between the work environment and employee motivation. ${ }^{1}$

The quality of an employee's work life would create a condusive work environment. According to Cascio, there are 9 components that influences the quality of qork life (QWL), i.e. enmployee involvement, equivalent compensation, work security, occupational safety, pride in their institution, carreer development, facilities provided, problem solving, and communication. ${ }^{2}$ A comfortable work life would improve the performance of the employee. According to a research by Saraji and Dargahi in 2006 on hospital workers at Teheran, health and work safety influences the performance. ${ }^{3,4}$ Yahya Al-Qutop and Harrim in 2011 also found similar findings in their research. Furthermore, a research on factory workers in Malaysia by Noor and Abdullah (2012) discovered that there was a correlation between employee involvement and work security with their work satisfaction (6).

Ogan Ilir District General Hospital is a D class hospital that has operated for 4 years and has 363 employees, 89 civil servants and 274 voluntary employees. However, their performance was not optimal. This was caused by many factors. According to the interviews with employees from the department of radiology, pharmacy, and the hospital manajement staff, it was caused by dissatisfaction with their work environment. The employees feel that they were not involved in the planning, policy making, and decision making process in their work fields. There were also dissatisfactions in how the problems between staff were solved, making them feel uncomfortable during work. Another problem was that they were assigned at positions that were not within their compentencies and there was no guarantee that the voluntary health staff would be appointed as permanent staff, therefore they prefer to find other jobs that was within their competencies.

This was compounded by the lack of opportunities to develop their carreer (only 6 of the 363 employees were able to extend their education) and lack of opportunities to obtain trianings. In 2017, the total number of trainings and courses that the hospital employees have 
participated in was only 108 (7). Inequal work load with inadequate compensation, large distances and difficult to access the hospital were also included in the reasons why many chose to find other work. In 2017 alone, 17 employees requested for transfers and 2 resigned (7). The lack of facilities, such as Personal Protective Devices (PPD) also caused inoptimal healthcare to be provided to the public.

Since the quality of their work environment influences their work performance, we wish to analyze its relationship. Also, this type of research has not been done at Ogan Ilir General Hospital. The results of this research is expected to be able to improve the performance of the employees and improve their work performance.

\section{LITERATURE RESEARCH}

Performance is a quantity or quality of work appearance or the work results of a person or a groups of persons achieved during their duties, which involves all the staff at the hospital, in addition to the functional and structural staff, to reach the organizational goals set $(8,9)$. Performance directs and influences the expected work behavior of a personnel in an organization (9). According to Gibson, Ivanevich and Donelly, personal performance is the basis of the organization's performance and is always influenced by the environment where the organization operates and is maintained. The larger number of personal needs is satisfied, the larger its influence against the performance (8). Performance evaluation is a continuing process performed by the manager to their subordinates and it evaluates how good the employee performed their jobs compared to the standards, which is then conveyed to the employee. Therefore, this process would help the employee to understand the roles, goals, expectations and success of their performance (8).

Wayne F Cascio (3) described the quality of work life as the degree where the employee can actively work and choose the work according to their field of interest and needs. He stated that there were 9 components that may improve the quality of work life, which is employee participation, carreer development, equivalent compensation, work security, the facilities provided, work environment safety, problem solving, and communication.

A successful implementation of the Quality of Work Life principles by an organization or institution is evaluated based on nine work life quality components, such as the involvement of employees during work, therefore providing and increasing work satisfaction, in return the organization would experience increased productivity and motivation to work, and reduced truancy (10). It is those components that was be researched and its relationship with the employee's performance was evaluated.

\section{RESEARCH METHODS}

This was a cross-sectional quantitative research performed at Ogan Ilir District General Hospital, South Sumatera. The data was collected using a proven valid and reliable questionnaire. 2 types of questionnaire was used, a work life quality questionnaire (the independent variable) for all the 363 employees at the hospital (89 civil servants and 274 voluntary employees) and an employee performance questionnaire for all the IV eschelon staff (the head of sections ) and the number of questionnaires provided depends on the number of their subordinates.

The primary data used was gathered from the questionnaire on the nine components of the quality of work life and employee performance. While the secondary data was from researching the 2018 documents of the hospital. The data was then analyzed using univariate, bivariate (Chi-square) and multivariate analysis.

\section{RESEARCH RESULTS}

Description of the Quality of Work Life and the Employees' Performance

\begin{tabular}{|c|c|c|c|}
\hline No & Quality of Work Life Components & Frequency ( 315 personnel) & Percenage (\%) \\
\hline \multirow[t]{3}{*}{1} & Employee Involvement/ Participation & & \\
\hline & Adequate & 126 & 40 \\
\hline & Inadequate & 189 & 60 \\
\hline \multirow[t]{2}{*}{2} & Carreer Development & & \\
\hline & Inadequate & 165 & 52.4 \\
\hline \multirow[t]{3}{*}{3} & Pride for the Hospital & & \\
\hline & Adequate & 118 & 37.5 \\
\hline & $\frac{\text { Inadequate }}{\text { FairCemperstion }}$ & 197 & 62.5 \\
\hline \multirow{2}{*}{4} & Fair Compensation & & \\
\hline & $\begin{array}{l}\text { Adequate } \\
\text { Inadequate }\end{array}$ & $\begin{array}{l}158 \\
158\end{array}$ & $\begin{array}{l}49.8 \\
50.2\end{array}$ \\
\hline \multirow[t]{2}{*}{5} & Work Security & & \\
\hline & $\begin{array}{l}\text { Adequate } \\
\text { Inadequate }\end{array}$ & $\begin{array}{l}153 \\
162\end{array}$ & $\begin{array}{l}48.6 \\
514\end{array}$ \\
\hline \multirow[t]{2}{*}{6} & Facilities Provided & & \\
\hline & $\begin{array}{l}\text { Adequate } \\
\text { dadeauate }\end{array}$ & $\begin{array}{l}129 \\
186\end{array}$ & $\begin{array}{l}41.0 \\
590\end{array}$ \\
\hline \multirow[t]{3}{*}{7} & Work Safety & & \\
\hline & Adequate & 134 & 42.5 \\
\hline & Inadequate & 181 & 57.5 \\
\hline \multirow[t]{2}{*}{8} & Problem Solving & & \\
\hline & $\begin{array}{l}\text { Adequate } \\
\text { Inadequate }\end{array}$ & 166 & 52.7 \\
\hline \multirow[t]{3}{*}{9} & Communication & & \\
\hline & Adequate & 141 & 44.8 \\
\hline & Inadequate & 174 & 55.2 \\
\hline & Performance & Frequency ( 315 personnel) & Percentage (\%) \\
\hline \multirow{2}{*}{10} & Adequate & 151 & 47.9 \\
\hline & Inadequate & & 51.1 \\
\hline
\end{tabular}

During this research, we discovered that the work life quality components were mostly inadequate. In addition, of the 315 employees, 164 (51.1\%) employees were considered to have ainadequate performance and 151 (47.9\%) employees had adequate performance.

The Correlation of the Quality of Work Life with Employee Performance

After the statistical analysis, we discovered that the 
quality of work life components was significantly correlated with the employees' performance, particularly the employee involvement/participation and the facilities provided to the employees. As stated in the following table.

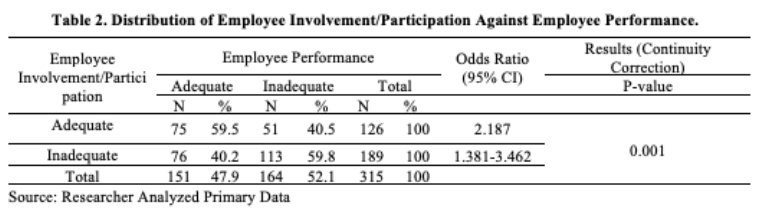

From the Chi Square analysis we discovered that the pvalue was 0.001 , which is less than the alpha $(5 \%)$. This indicates that there was a significant correlaton between employee involvement/participation with their performance. We also discovered that the Odds ratio (OR) was 1.381-3.462, which meant that individuals that had inadequate involvement was 1.381-3.462 times more likely to have inadequate performance compared to those with adequate involvement.

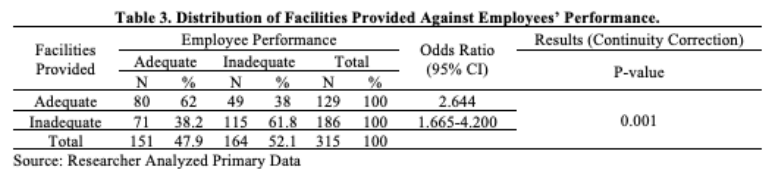

From the Chi-Square analysis, we discovered dthat the p-value was 0.000. It was smaller than the alpha (0.05), which meant that there was a significant correlation between the facilities that were provided to the employees with their performance. We also discovered that the OR was 1.665-4.200, which meant that employee that feel that the facilities that were provided were inadequate had a 1.665-4.200larger probability to also have lower performance compared to those that feel that the facilities that they had were adequate.

The Components of the Quality of Work Life that Influences the Employees' Performance

\begin{tabular}{llrrrc}
\multicolumn{7}{c}{ Table 5. Results of the Multivariate Analysis. } \\
\hline No & Variables & B & P-value & OR & $95 \% \mathrm{Cl}$ \\
\hline 1 & Employee & 0.784 & 0.001 & 2.190 & $1.363-3.518$ \\
\hline 2 & Facilities provided & 0.982 & 0.000 & 2.670 & $1.617-4.407$ \\
\hline 3 & Work Safety & 0.028 & 0.911 & 0.972 & $0.590-1.600$ \\
\hline Source: Researcher Analyzed Primary Data & & & &
\end{tabular}

The multivariate analysis indicated that the variables of the quality of work life that correlates with the employees' performance were the employee involvement/participation and the facilities that they received. The work safety variable acted as the controlling variable. The most dominant influencing factor for the performance of the employees of the Ogan Ilir General Hospital in 2018 was the facilities that were provided to the employees $(\mathrm{OR}=2.670)$, where respondents or employees that feel that the facilities were inadequate was 2.670 more likely to also have inadequate performance compared to those that feel that they have received adequate facilities from the hospital.

\section{DISCUSSION}

\section{Research Limitations}

Since this was a quantitative research that used questionnaires for obtaining its primary data, it was impossible to avoid any bias. The questionnaire data was done in the hospital and the head of the section was present, therefore there might be some reluctance in answering the questions. To reduce the chances of that happening, the researcher and enumerators explained to the respondent the objectives and goals of the questionnaire before they fll in the questionnaire and guarantee the confidentiality of the data from the respondent. The researcher also minimalized bias by employing 5 enumerators and distributing and gathering the questionnaires on the same day.

\section{A Description of the Quality of Work Life and Employees' Performance}

Most of the repsondents have D3 and D4/S1 backgrounds. This is a human resource potential that was not optimally used and unequal workload distribution caused the employees to feel that they were not involved in the decision making their work. Lack of communication caused inter-employee conflicts and was compounded with unclear problem solving influenced the employees' discipline and and lower motivation. There was also a lack of chances to develop their personal potential through education and training.

Difficulty in obtaining carreer promotions within their own compentencies was also another issue in maintaining personnel within the institution, most personnel were unwilling to stay at the institution and spend their whole carreers there. There was also a lack of belonging and pride for the institution, which should be an important matter for the management, because it would be a positive influence for the institution's vision and mission. Some employees did not feel secure and has tried to be responsible although working in an environment without guaranteed security. This was also compounded with the lack of compensation for employees working in higher risk areas and no facilities such as housing, work vehicles, and a supply of food and drinks for the night shift.

The hospital is obligated to make the employees feel secure with their jobs and their work environment, so that they would be able to work optimally. Management of human resources by maintaining the quality of work life at the hospital is one way to provide guidance for the employees and would create a 
condusive, efficient, and effective work place. It would also motivate the employees to work better. Human resources guidance is a considerable asset in health development and regional development.

\section{The Correlation Between the Quality of Work Life and the Employees' Performance}

According to information from the respondens, this research also discovered that employee involvement had a significant influence against the employees' performance. The respondents felt that they were not involved in the planning of various decisions and evaluations related to their work and tasks. Some felt that their superiors did not pay attention or listen to their suggestions, opinions, and complaints that caused the respondents or employees hard to be ordered. This situation is unacceptable, therefore a solution must be found for this problem. If not, it might influence the performance of employees with good performance and hinder them to reach the targeted performance.

This finding was comparable to what Heni Hendrawati found at the Banten Provincial Health Office that stated that there was a significant correlation between the employee involvement component with the employees' performance (11). Nawawi wrote that every employee should be involved in the decision making process and its implementation according to each position, therefore gaining work security and satisfaction. He also provided examples on how to establish employee involvemen in an organization or institution, which is by creating a main team and meeting that not only convey orders, but also listen to inputs and suggestions or the opinions of the employees (12). The considerable number of employees that would prefer to be involved in the hospital administration activity creates an opportunity for employee development, but it does not mean that all the employees must be involved in the decision making and policy making process within the hospital.

In addition to employee involvement/participation component, the facilities provided component also has a significant correlation with the employees' performance. The employees at Ogan Ilir District General Hospital stated that they have not received adequate facilities that guarantees their safety, security, and comfort during work. Therefore, many tasks cannot be completed optimally and lowering their work performance.

Another research that found that the facilities received has a significant correlation with the employees' performance was a research by Hasiholan (13) on the nurses at Jakarta Heart Hospital. According to Hasiholan (13), Jakarta Heart Hospital provided medical and non-medical support facilities for their employees that aided them in work. This was why the nurses stated that the hospital has provided adequate facilities and the performance of the nurses increased (13). Cascio (2003) stated that improvement of work facilities would improve employee performance and this is what happened at Jakarta Jeart Hospital. Nawawi (12) also stated that the facilities that is provided to the employee would increase their energy, resulting in high motivation to work. The supporting factors for employee capabilities are staff competence, technological infrastructures, and climate to act (14). Providing good facilities would circumvent and prevent the possibility of obstacles from forming.

\section{Quality of Work Life Components that Influences Employees Performance}

From the multivariate analysis with the double logistical regression prediction or determinant model, we discovered that there was three quality variables of the quality of work life that has a larger influence to the employees performance compared to the other six components. Of those components, the most dominant component was the facilities provided. There is a large possibility that the variable was the main cause that the emplyees were not willing to work there for long periods for the past 5 years.

One of the factors that supported the results of this research was the results of the open interviews with several employees. One employee at the pharmacy instalation stated that the laptop and printer used for keeping the data for stocking, recording and reporting, drug warehouse, and medicine storage cabinet was insufficient. The warehouse was not large enough to keep al the drugs, some had to be stored in other buildings, which would also be an encumberance during work. While the employee at the radiology installation complained on the lack of supplies and the lack of safety and security equipment that they needed to maintain their own health.

Another variable that has a large influence on the employees' performance is their own involvement. Some employees felt that they were not involved in the planning and decision making process for their area of work. A large part of the employees at the hospital were Voluntary Staff, which was why they were not involved too much in the planning and decision making process at the hospital.

Lastly, was the work environment safety. This variable was strongly related to the facilities provided. Employees at the radiology installation are often exposed to X-ray radiation, thus they require tools to protect them from the radiation they are exposed to during work. However, during the open interview some stated that there were insufficient protective gears (aprons), and there was only a few handgloves, and masks, therefore exposing them to the dangers of radiation. The employees felt that their safety was 
largely ignored. And then, there were uneven flooring in the hallways, some tiles were broken or damaged, and slippery floors because of water leaking from the Air Conditioner that was not immediately wiped. This was mostly of the inadequate maintenance process for the equipemt and the long repairment process. The cleaning service officer was also hired directly by the hospital and not outsources to a third party, which is why the cleanliness was not up to standards. All of the components above would greatly influence the safety of the employees and any patients visiting the hospital.

\section{CONCLUSION}

The quality of work life of the employees of Ogan Ilir District General Hospital did not receive adequate attention. This was evident in the results of the survey where most employees stated that almost all the work life components researched were inadequate. From the analysis on the correlation between the quality of work life and the employees performance, we discovered that there were 2 components that was significantly related to performance, they were the employee involvement/participation and the facilities provided and the most dominant factor that influences the employees' performance was the facilities that were provided to the employees.

he government, but Case Fatality Rate will determine the success of such policies. The main goal in this pandemic is to reduce the mortality rate, with various forms of national policies in breaking the chain of COVID-19 transmission.

\section{ACKNOWLEDGMENT}

This work is supported by Administration and Health Policy Department, Faculty of Public Health, Universitas Indonesia and Graduate School of Public Health, Universitas Muhammadiyah Prof DR Hamka.

\section{REFERENCES}

1. Muljani BD, Alhabsji T, and Hamid D. Profits : Jurnal adm Bisnis 2012;6(2). Downloaded from http://www.ejournalfia.ub.ac.id/index.php/profit/ article/view/239/555.

2. Cascio WF. Managing Human Resources Productivity, Quality of Work Life, Profits. 6th Edition. The McGraw-Hill Companies, Inc. New
York, 2003.

3. Yahya Al-Qutop M-A, and Harrim H. Quality of Worklife Human Well-being Linkage: Integrated Conceptual Framework. Int J Bus Manag 2011;6(8):193-205. Downloaded from http://www.ccsenet.org/journal/index.php/ijbm/ar ticle/view/11571.

4. Saraji GN and Dargahi H. Study of Quality of Work Life (QWL). Iran J Publ Heal 2006;35(4):8-14. Downloaded from http://citeseerx.ist.psu.edu/viewdoc/download?do $\mathrm{i}=10.1 .1 .603 .2552 \& \mathrm{rep}=\mathrm{rep} 1 \&$ type $=$ pdf

5. Noor SM and Abdullah MA. Quality Work Life among Factory Workers in Malaysia. Procedia Soc Behav Sci 2012;35:739-45. Downloaded from

https://www.sciencedirect.com/science/article/pii /S1877042812004569.

6. RSUD Kabupaten Ogan Ilir. Profil Kesehatan Rumah Sakit Umum Daerah Kabupaten Ogan Ilir. Indralaya, Sumatera Selatan, 2017.

7. Hafizurrachman. Manajemen Pendidikan dan Kesehatan. $1^{\text {st }}$ edition. CV. Sagung Seto. Jakarta, 2009.

8. Yaslis Ilyas. Kinerja Teori, Penilaian dan

Penelitian. Fourth edition. University of Indonesia, Faculty of Public Health. Depok, 2012.

9. Wahyuningsih N. Peranan Quality of Work Life Dalam Peningkatan Kinerja Pegawai. 2016.

Downloaded from

http://download.portalgaruda.org/article.php?artic

le $=447053 \& \mathrm{val}=9459 \&$ title $=$ PERANAN

QUALITY OF WORK LIFE DALAM

PENINGKATAN KINERJA PEGAWAI

10. Hendrawati H. Kualitas Kehidupan Kerja/Quality of Work Life (QWL) dan Hubungannya dengan

Kinerja Pegawai Dinas Kesehatan Provinsi

Banten Tahun 2011. Universitas Indonesia. 
Depok, 2011.

11. Hadari Nawawi. Manajemen Sumber Daya

Manusia Untuk Bisnis Yang Kompetitif. Gajah

Mada University Press. Yogyakarta, 2008.

12. Hasiholan O. Hubungan Quality Of Work Life

(QWL) Terhadap Kinerja Perawat Ruang Rawat

Inap Rumah Sakit Jantung Jakarta Tahun 2016.

Universitas Indonesia. Depok, 2016.

13. Ayuningtyas D. Perencanaan Strategis Untuk

Organisasi Pelayanan Kesehatan. 2 ed. Jakarta:

Rajawali Press. Jakarta, 2015. 